\title{
Architecture, ecology and biogeochemistry of Phaeocystis colonies
}

\author{
C.E. Hamm \\ Alfred Wegener Institute for Polar and Marine Research, Postfach 120161, D-27515 Bremerhaven, Germany
}

Received 18 October 1999; accepted 3 February 2000

\begin{abstract}
This paper discusses structure and function of the Phaeocystis colony skin, and relates them to the specific impact of Phaeocystis colonies on ecology and biogeochemistry. The potential advantage of the recently discovered tough skin around the colonies of Phaeocystis globosa is discussed in context with the metabolic costs of this structure, and compared to potential functions of structures around other phytoplankton. It is further proposed that mainly small, fast-growing pathogens and predators will be deterred by the colony skin. It will be shown that these theoretical predictions are consistent with available data from the literature, and can explain the dominance of the colonial form in Phaeocystis blooms. Finally, the peculiar biogeochemistry of Phaeocystis colonies, especially the sedimentation of Phaeocystis-derived organic matter, is argued to be a function of the susceptibility of Phaeocystis colonies to certain grazers, which in turn is strongly determined by the architecture and function of the colony skin. During the exponential phase of the bloom, Phaeocystis-derived organic matter can efficiently sink in faecal material of large zooplankton, which actively feed on the colonies. However, the integrity of the colony skin, and consequently its protection for the cells therein, seems to be closely coupled to the phase of active growth. Accordingly, the cells are massively affected by small grazers and pathogens and thus rapidly disintegrate after the culmination of the bloom, so that sedimentation of Phaeocystis-derived organic matter becomes probably restricted to the more refractory extracellular components of the colonies. (c) 2000 Elsevier Science B.V. All rights reserved.
\end{abstract}

Keywords: Phaeocystis colony; colony skin; mechanical defence; top-down control; ecology; sedimentation

\section{Mechanical defences of phytoplankton}

Biological architecture (i.e. structure, composition, and mechanical properties) is a product of evolution and usually results from the need to unify counteracting requirements (e.g. Bertness, 1981; Tollrian, 1995). In phytoplankton, selection pressure presumably forces a trade-off between efficient protection against pathogens and predators, and fast growth rates. Globally distributed genera like Phaeocystis, which regularly form large blooms (Lancelot et al., 1998), appear

E-mail address: chamm@awi-bremerhaven.de (C.E. Hamm). to have optimised the product of growth and protection in many marine ecosystems. While many studies imply that grazing pressure on Phaeocystis colonies in the field is reduced compared to Phaeocystis flagellates (Weisse et al., 1994 and refs. therein), knowledge on antigrazing mechanisms of Phaeocystis colonies or other marine phytoplankton is still sparse. As it possesses a unicellular $(6 \mu \mathrm{m})$ and a colonial stage (up to ca. $10 \mathrm{~mm}$ with several 1000 cells) with similar growth rates, Phaeocystis is an intriguing object to study potential defence mechanisms of phytoplankton and their impact on ecology and biogeochemistry. In this paper, I will discuss how 
the properties of Phaeocystis colonies might reflect the necessities for both growth and protection.

\subsection{The Phaeocystis colony skin is a cheap mechanical defence strategy}

As shown by Hamm et al. (1999), colonies of Phaeocystis globosa are surrounded by a thin yet mechanically very stable skin. In combination with a pore size of $<4.4 \mathrm{~nm}$, the toughness of the skin probably makes the cells within the colony inaccessible to a large number of organisms, especially viruses, bacteria and protozoa, which could otherwise readily infect or ingest organisms of the size of Phaeocystis flagellates. However, while efficient protection against small or filter-feeding organisms is very likely provided by the colony, its protective value seems to be insignificant in other cases, for instance against large copepods or euphausiids (Weisse et al., 1994; Hamm et al., 2000). This indicates that mechanical, and not chemical, properties are mainly responsible for the protective property of the colony envelope. Further strengthening of the skin, e.g. as a protection against large and raptorial zooplankton (e.g. Calanus finmarchicus, Hansen et al., 1990; Hansen, 1992, or Thysanoessa raschii, Hamm et al., 2000) would most likely decrease the growth rates, as more unproductive assimilates would have to be produced, and a thicker skin could restrict the diffusion of nutrients to the cells. Apparently, this disadvantage is not balanced by a potentially better protection against larger predators, which only consume a small percentage of the primary production of Phaeocystis blooms (Hansen and Van Boekel, 1991). Conversely, a less sophisticated architecture of the construction of a colonial envelope would probably hamper bloom formation: Comparable haptophytes such as unicellular poisonproducing Chrysochromulina (Hanslik and Rahmel, 1995) or Corymbellus, which forms small colonies (Green, 1976), only sporadically dominate phytoplankton blooms. Also, the flagellate stage of Phaeocystis, even though at least as fast-growing as the colonies (Baumann et al., 1994), is not known to accumulate biomasses in the field comparable to those of the colonies. A possible reason is that the small Phaeocystis cells are difficult to recognise and are therefore easily overlooked, if they are not expected. On the other hand, blooms dominated by other small flagellates, e.g. Chrysochromulina (Hanslik and Rahmel, 1995) or Pyramimonas (Bird and Karl, 1991; Gradinger, 1996) have been perceived by marine scientists. Thus it appears unlikely that unnoticed Phaeocystis flagellates dominate large blooms as do the colonies, even though they may often be overlooked if other phytoplankton dominate the bloom.

Examples where only one principle (need for growth or need for protection) is necessary can be instructive: The resting stages of phytoplankters do not have to grow, and thus can reinforce their outer layers to efficiently protect their protoplasts against pathogens and predators. Consequently, many dinoflagellates (Wall and Dale, 1968) and diatoms (e.g. Thalassiosira bulbosa, Syvertsen and Hasle, 1994 or Chaetoceros socialis, Eilertsen et al., 1981) use strengthend versions of their respective typical cell walls for their resting spores. Conversely, if protection is not necessary, for instance in Phaeocystis cultures derived from colonies, the percentage of flagellates is often much higher than in the field, to the extent that sometimes colonies are not present at all (Janse et al., 1996). Finally, the induction of colonies from single cells of the green alga Scenedesmus acutus by kairomones (infochemicals) from Daphnia (Cladocera), Eudiaptomus (Copepoda) and Brachionus (Rotifera) (Lürling and Van Donk, 1997) shows that mechanical protection may be switched on and off, depending on whether certain predators are present or not. Though an analogous induction of colony formation is often discussed for Phaeocystis, conclusive evidence is still missing.

As single and colonial cells of Phaeocystis have similar growth rates (Guillard and Hellebust, 1971; Grimm and Weisse, 1985), the allocation of the material needed to build the colonial matrix obviously does not hamper the cell metabolism. In other words, the high stability of the colony skin is probably achieved with economical amounts of material. In fact, the colony envelope of Phaeocystis globosa is built with only small amounts of polysaccharides - supposedly the main components of the extracellular colonial material - which constitutes only ca. 10-34.5\% of the total colony biomass (Van Rijssel et al., 1997). Since Phaeocystis globosa cells are able to accumulate a storage of glucan, which can constitute more than $40 \%$ of the cell carbon (Janse et al., 1996), the percentage of extracellular polysaccharides is 
probably even lower. Another economical advantage for the colonial cells is that the intact skin itself appears to be very resistant to bacterial attack. This is remarkable, as much of the extracellular material is built of potentially easily degradable polysaccharides (Janse et al., 1999). Also, it suggests that the material used for colony formation is a one-time investment that does not need maintenance or reconstruction.

\subsection{Analogies and differences within the genus and to other algae}

The concept of the colony skin as a cheap mechanical defence is based on properties of Phaeocystis globosa. Since three other colony-forming species of the genus Phaeocystis- $P$. pouchetii, $P$. antarctica and $P$. jahnii-exist, the properties of $P$. globosa need not be representative of the genus. On the other hand, prominent features with important functions are in general functionally conservative on the genus level. Accordingly, the mechanical protection of cells, which would clearly be a fundamental function of the $P$. globosa colony skin, should principally be given by the analogous structures of $P$. antarctica or $P$. pouchetii as well. Nevertheless, functional differences between the colonies of the different species are probable. A geometric difference to the spherical $P$. globosa colony is indicated by the colony morphology of $P$. pouchetii, which typically has several lobes protruding from a central cell-free region. This and the fact that $P$. pouchetii colonies seem to be easier to disrupt than $P$. globosa colonies (Jacobsen, pers. comm., 1999) indicate that it follows a different antigrazing strategy than $P$. globosa. As an example, it is thinkable that the geometry of $P$. pouchetii colonies enables them to have the advantage of a larger diameter than the other Phaeocystis colonies with the same amount of cells, but makes them more susceptible to mechanical disruption. Colonies of the recently described $P$. jahnii, which appear to be largely amorphous and seem to lack a colony skin (Zingone et al., 1999), may offer an even cheaper, but also less effective mechanical defence than the highly organised colonies of $P$. globosa, $P$. antarctica, and $P$. pouchetii.

Many colonial planktonic algae of widely diverse taxonomic origin such as $C$. socialis (Bacillariophyceae), Volvox (Chlorococcales), or Uroglena (Chryso- phyceae) have a geometry similar to that of the more organised Phaeocystis colonies. Their colonial cells are distributed at the periphery of a large cell-free space. The connecting colonial material of these colonies is often described as a gel or mucilage (Doers and Parker, 1988), sometimes (as in Volvox) implicitly as a cell wall (Ertl et al., 1992). Another geometric analogy exists in unicellular bloom-forming microalgae, such as the large centric diatoms Thalassiosira or Coscinodiscus. Here, the cell plasma and the chloroplasts are essentially located at the periphery of a large cell and protected by a rigid siliceous cell wall. Colonies of planktonic Cyanophyta, e.g. Microcystis or Aphanizomenon, are, like P. jahnii, typically less organised. Their cells are distributed throughout the colonies, and the colonies often have irregular, asymmetric forms.

Clearly, the mechanical properties of the tough but pliable colony skin (Hamm et al., 1999) differ fundamentally from those of the rigid siliceous frustules of the diatoms. Copepods feeding on Phaeocystis colonies and diatoms too large to be ingested as a whole need different strategies to gain access to the cell biomass. While diatom frustules may be crushed like a nutshell by copepod mandibles, this appears to be impossible for Phaeocystis colonies. Judging from their physical properties, which resemble those of a plastic bag or a thin metal foil (Hamm et al., 1999), they would have to be cut or torn apart by the copepods. Still, certain common features, viz. a large size and a stable shell or skin, indicate that Phaeocystis colonies and large diatoms may be protected against a similar spectrum of grazers or pathogens. In contrast to the Phaeocystis colony envelope, the mechanical barrier provided by the diatom frustule seems to have several unavoidable weak spots (i.e. the girdle region, the rimoportulae and the areolae), which are used by specialised parasitoid protists to gain access to the plasma (Schnepf and Drebes, 1977, 1986; Raghukumar, 1978; Kühn, 1997). However, it cannot be excluded that specialised, small organisms have the means to enter Phaeocystis colonies and feed on the cells from inside the colony. Corresponding examples exist in the rotifers Proales parasitica and Cephalodella edax (Hollowday, 1993), which are able to penetrate and feed inside Volvox and Uroglena colonies, respectively, or the parasitoid protist Rhizopodium beauchampi 
Table 1

Sizes and growth rates of potential mortality factors and their impact on different stages of the Phaeocystis life cycle (+, cells are affected; o, not known; -, cells are not significantly affected. Note that though the depicted growth rates are only examples of the respective groups, the general tendency can be regarded as realistic)

\begin{tabular}{|c|c|c|c|c|c|}
\hline $\begin{array}{l}\text { Potential mortality } \\
\text { factors }\end{array}$ & $\begin{array}{l}\mu \max \\
\left(\mathrm{h}^{-1}\right)\end{array}$ & Size & $\begin{array}{l}\text { Single cells } \\
(\text { ca } 6 \mu \mathrm{m}), \mu \max \\
\left(\mathrm{h}^{-1}\right)=0.08^{\mathrm{a}}\end{array}$ & $\begin{array}{l}\text { Cells in intact colonies }> \\
100 \mu \mathrm{m}, \mu \max \left(\mathrm{h}^{-1}\right)=0.06^{\mathrm{a}}\end{array}$ & $\begin{array}{l}\text { Cells in disrupted/ } \\
\text { deteriorating colonies }\end{array}$ \\
\hline Viruses & $0.2^{\mathrm{b}}$ & $0.14 \mu \mathrm{m}$ & $+^{b}$ & $-{ }^{b}$ & $+^{b}$ \\
\hline Bacteria & 1 & ca. $1 \mu \mathrm{m}$ & o & $-^{c}$ & $+^{c}$ \\
\hline Nanoflagellates & $0.133^{d}$ & $2-20 \mu \mathrm{m}$ & o & o & o \\
\hline Dinoflagellates & $0.026^{\mathrm{d}}$ & ca. $20-50 \mu \mathrm{m}$ & $++^{e, f}$ & $-{ }^{\mathrm{f}}$ & $+{ }^{f}$ \\
\hline Ciliates & $0.055^{\mathrm{d}}$ & ca. $70-120 \mu \mathrm{m}$ & $+^{e, f, g, h}$ & $-^{e, f, g}$ & $+^{\mathrm{e}, \mathrm{f}, \mathrm{g}}$ \\
\hline Copepods & $0.0066^{\mathrm{d}}$ & ca. $0.2-10 \mathrm{~mm}$ & $+{ }^{\mathrm{i}} /-^{\mathrm{j}}$ & $+{ }^{\mathrm{k}, 1, \mathrm{~m}, \mathrm{n}} /-^{\mathrm{n}, \mathrm{o}, \mathrm{p}}$ & $+^{p}$ \\
\hline Euphausids & $<0.005$ & ca. $15-60 \mathrm{~mm}$ & $+q$ & $+^{\mathrm{r}, \mathrm{s}}$ & o \\
\hline Decapod larvae & $<0.005$ & $>0.5 \mathrm{~mm}$ & $+t-{ }^{t}$ & $+^{u}$ & $\mathrm{o}$ \\
\hline Fish & $<0.005$ & $>1 \mathrm{~cm}$ & $\mathrm{o}$ & $+^{v}$ & $\mathrm{o}$ \\
\hline
\end{tabular}

a Data taken from: Guillard and Hellebust, 1971.

b Jacobsen et al., 1996.

c Thingstad and Billen, 1994.

d Hansen et al., 1997.

e Weisse and Scheffel-Möser, 1990.

${ }^{\mathrm{f}}$ Hansen et al., 1993.

g Admiraal and Venekamp, 1986.

h Hansen et al., 1993.

i Hansen, 1992.

j Verity and Smayda, 1989.

k Tande and Båmstedt, 1987.

${ }^{1}$ Weisse, 1983.

${ }^{\mathrm{m}}$ Hansen and Van Boekel, 1991.

n Schnack, 1983.

o Daro, 1985.

p Estep et al., 1990.

${ }^{\mathrm{q}}$ Marchant and Nash, 1986.

r Sieburth, 1960.

s Hamm et al., 2000.

t Hansen, 1992.

"Hamm and Rousseau (unpublished).

${ }^{v}$ Bullen, 1908.

(Chytridiomyceta), which is able to infect the cells within Eudorina colonies.

\section{Impact of defence strategy on ecology}

In the previous sections I have discussed the fact that the physical properties of the colony skin are suited to reduce grazing pressure on the cells in Phaeocystis colonies. But how would this translate to the role of Phaeocystis colonies in the ecosystem, and its impact on the ecosystem itself?
Diverse organisms, ranging from viruses to vertebrates, with sizes between ca. $140 \mathrm{~nm}$ (viruses) and several $\mathrm{cm}$ (krill, fish larvae), potentially decimate phytoplankton. It is evident that a specific defence mechanism which leaves room for competitive growth rates cannot offer complete protection against the whole range of these organisms. Thus, phytoplankton with an efficient defence against certain feeding mechanisms is likely to be susceptible to infection or attacks from organisms with different strategies. Along with its physiological characteristics, the defence strategy of a phytoplankton organism 


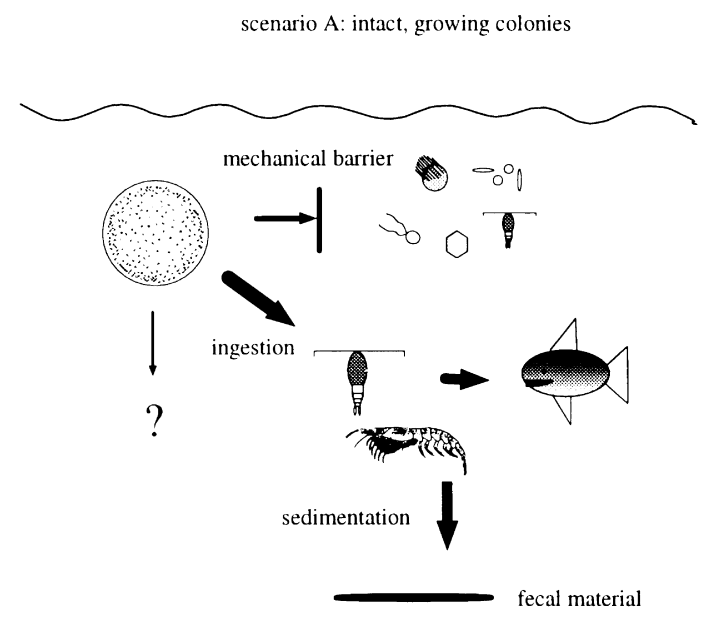

Fig. 1. Hypothetical effects of a protective colony skin on the fate of Phaeocystis-derived organic matter during the exponential phase of a Phaeocystis bloom: Viruses, bacteria, nanoflagellates, ciliates and small copepods will be deterred, but ingestion by large zooplankton such as copepods and euphausids is possible. This permits bloom formation, but also transfer of organic matter to higher trophic levels, and-in faecal material-to deeper layers. The arrows indicate the relative importance of the different pathways. Organisms not to scale.

is an adaptation to a distinct ecological niche. In the case of Phaeocystis, the different defence strategies of the colonies and the flagellates are reflected by the organisms which feed on them: while the flagellates are mainly affected by a broad spectrum of smaller, fast-growing organisms, large predators tend to feed more efficiently on the colonies than on the flagellates (Table 1).

Though this view is simplified and does not account for the complexities of interactions between grazers and prey, it clearly shows how biomass produced by single Phaeocystis cells supports a fundamentally different heterotrophic community than biomass in the Phaeocystis colonies. The higher growth rates of the organisms affecting Phaeocystis single cells, such as ciliates and dinoflagellates, compared to those of the organisms feeding on Phaeocystis colonies, such as euphausids (Table 1), might be decisive for dominance of the colonies in Phaeocystis blooms. Conversely, it might be expected that larger copepods or euphausids thrive during Phaeocystis blooms, while protozooplankton, being unable to feed on the colonies and being grazed by mesozooplankton, will remain at a lower biomass level.
In fact, if related to the abundant phytoplankton biomass, protozooplankton has been shown to be relatively unimportant during Phaeocystis blooms which consist mainly of intact colonies (Van Boekel et al., 1992; Brussaard et al., 1995; Garrison et al., 1995), but sharply increase in abundance when the colonies start to disintegrate. The effect of these blooms on the mesozooplankton community is ambiguous. While Phaeocystis pouchetii blooms actually coincide with the most intensive growth and production of herbivorous copepods in the Barents Sea and coastal areas of northern Norway, blooms of Phaeocystis globosa colonies seem to have an adverse effect on most of the indigenous copepods of the North Sea (Weisse et al. 1994). Though this may be explained by speciesspecific differences of the Phaeocystis colonies or the grazing strategies of the copepods, it remains enigmatic why such fundamentally different effects should occur within these principally similar plankton communities.

\section{Impact of defence strategy on biogeochemistry}

Having optimised defence and growth for many marine environments, Phaeocystis colonies influence the composition and limit the efficiency of the heterotrophic community, and are able to form large, almost monospecific phytoplankton blooms. But what is the impact of the defence strategy on nutrient uptake and fate of the biomass accumulated during such blooms?

\subsection{Biogeochemical impact during the exponential phase of the bloom}

Phaeocystis blooms deplete nutrients in different ratios than do other phytoplankters. While the $\mathrm{C} / \mathrm{N}$ ratio of Phaeocystis colonies is only slightly higher than the Redfield ratio (Verity and Smayda, 1989), the $\mathrm{C} / \mathrm{P}$ uptake ratio has been shown to be $40 \%$ higher than the Redfield ratio (Arrigo et al., 1999). These ratios are consistent with recent findings that the colony skin contains amino groups, most likely belonging to proteins (Hamm et al., 1999), and the unlikeliness that the colony skin contains phosphorous in significant amounts: in contrast to nitrogen, phosphorous is mainly confined to intracellular compounds, e.g. in membranes (as phospholipids), DNA, sugars or phosphates of nucleic acids. A high 
scenario B: stationary, deteriorating colonies

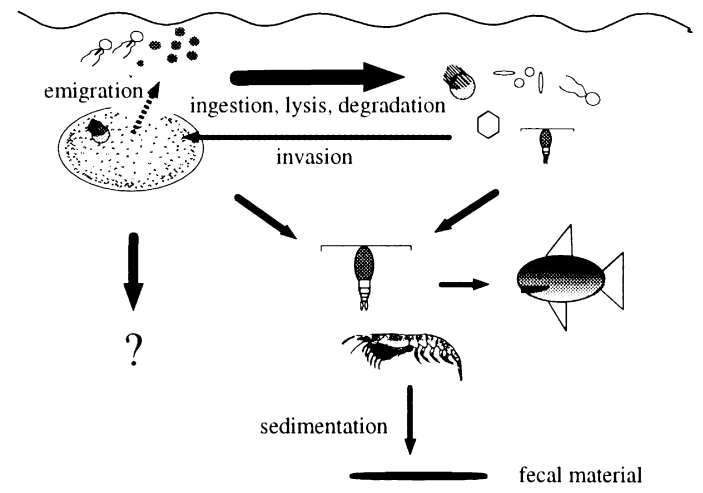

Fig. 2. Hypothetical effects of the loss of protection by the colony skin: small heterotrophic organisms efficiently decimate released cells, and accessible cells in the colony. This leads to a rapid decline of the bloom and retention and remineralisation of organic matter at the surface. Sedimentation of refractory extracellular material from the colonies is likely.

nutritional value of Phaeocystis colonies (including the cells), as indicated by their fatty acid composition (Hamm et al., 2000; Hamm and Rousseau, unpublished), would make them a valuable food. Since the mechanical defence mechanism described for Phaeocystis colonies seems to be selectively directed against smaller organisms, sedimentation of organic matter via faecal material, which is particulary efficient when caused by large zooplankton (Small et al., 1979), is more likely to occur in Phaeocystis colony blooms than in phytoplankton with different defence strategies, e.g. small flagellates, including those of Phaeocystis. Such a scenario is described by Hamm et al. (2000), where krill fed on Phaeocystis pouchetii when colonies were intact and actively growing, and Phaeocystis-derived organic matter sedimented in faecal material of krill (Fig. 1).

\subsection{Fates of extracellular colony material and cells after culmination of the bloom}

A mechanical defence structure such as a shell (diatom frustules, foraminiferan test, dinoflagellate armour) or a skin (such as the Phaeocystis skin) is likely to be difficult to degrade, and thus most likely survives the cytoplasm or cells it protects (Thingstad and Billen, 1994). In large areas of the sea floor, shells of diatoms, radiolarians and foraminiferans are the most important components in accumulating sediments. Suspended aggregates of Phaeocystis-derived organic matter in the North Sea were found to be virtually devoid of the essential polyunsaturated fatty acids (Hamm and Rousseau, unpublished), indicating that they contained the refractory material of the Phaeocystis colonies, that is, probably the colony skin (Hamm et al., 1999). Accordingly, Janse et al. (1999) have shown that storage polysaccharides from Phaeocystis cells are degraded much faster than the extracellular heteropolysaccharides of the colony.

A potential pathway of this nutritionally unattractive colonial material is aggregation and sedimentation. Sinking rates of aggregates depend on their size, but also on their excess density. This is consistent with the observation that Phaeocystis colony aggregates typically do not sink as efficiently as do the diatom aggregates (Riebesell, 1995; Hamm and Rousseau, unpublished), which contain their own skeletal material as ballast. Still, slow-sinking but refractory organic matter, which is mainly derived from the colony matrix (Thingstad and Billen, 1994; Hamm and Rousseau, unpublished), may cause efficient sedimentation of Phaeocystis-derived organic matter. Indeed, such a mechanism has been proposed to be responsible for the sedimentation of amorphous material after a Phaeocystis bloom in the Balsfjord (Riebesell et al., 1995).

The fate of the colony cells differs fundamentally from that of the colony material. Scanning Electron Microscopy (SEM) and Transmission Electron Microscopy (TEM) data suggest that the colony cells do not contain any visible, potentially protective features (Hamm, unpublished results; Van Rijssel, pers. comm., 1999, respectively). To my knowledge, this is in contrast to most other phytoplankton, even solitary cells of similar size, including Phaeocystis flagellates, which are covered with scales (Parke et al., 1971). Thus, once liberated and deprived of their protective skin, colony cells are probably particularly susceptible to all kinds of grazing or infection (Fig. 2). This is consistent with findings by Van Boekel et al. (1992) and Brussaard et al. (1995), who observed that unusually massive cell lysis was the main cause of the rapid decline of Phaeocystis blooms. 


\subsection{Analogies and differences to other algae}

The liberation of organic matter due to massive cell lysis after the culmination of Phaeocystis blooms seems to be unique and is not known in this dimension from other phytoplankton. The sedimentation of Phaeocystis-derived organic matter in krill faecal strings observed in the Balsfjord (Hamm et al., 2000) indicated that there might be an efficient way in which nutrient-rich Phaeocystis-derived organic matter could be exported, like other phytoplankton, to deeper layers. However, analogous to aggregate sedimentation, the efficiency of sedimentation in faecal material not only depends on the size of the zooplankton responsible for faecal pellet production, but also on the quality of the ingested food: both specific density and degradability of organic matter within faecal material are functions of the diets on which the faecal pellets have been produced. Faecal material containing mineralised phytoplankton like coccolithophorids or diatoms has been shown to be significantly denser, and thus sink faster, than faecal material containing flagellates (Cadée et al., 1992). Additionally, faecal material containing diatoms degraded more slowly than faecal pellets produced on a nanoflagellate diet (Hansen et al., 1996). Finally, though krill faecal strings sink fast, they tend to degrade rapidly and disintegrate before reaching depths of more than $100 \mathrm{~m}$ (Cadée et al., 1992). The colony skin and the colony mucus presumably sink within aggregates to larger depths (Riebesell et al., 1995; Passow and Wassmann, 1994). Though this appears to be an efficient mechanism for the sedimentation of Phaeocystis-derived material in particular, it is not clear if it really is a unique feature of Phaeocystis colonies, or if refractory material from other algae, e.g. the transparent exopolymeric particles (TEP, Passow and Alldredge, 1995) derived from diatoms, have a similar fate (sensu Logan et al., 1995).

\section{Perspectives for further research}

The hypotheses presented here describe fundamental, qualitative mechanisms, and may be valuable for further concepts on how defence strategies of phytoplankton might affect their ecological and biogeochemical impacts. Further studies will be necessary to understand construction and functioning of the Phaeocystis colonies in detail, e.g. by chemically analysing isolated colony skins, and by studying their growth, e.g. with experiments similar to those used to study cell wall growth, such as extensibility of the colony skin under different conditions.

For a refined understanding of the impact of the colony skin on the general role of the genus Phaeocystis within the ecosystem, it would be important to study potential variabilities of the colony skin as functions of different species and strains of Phaeocystis, and as functions of different abiotic conditions, such as nutrient concentrations, which seem to be critical for the integrity of the colonies and thus the accessibility of the cells therein. Another important ecological question is whether the formation and strength of the colony skin is inducible by the presence of certain predators. The question of how efficient the defence strategy of a colony skin is when confronted with different feeding strategies may be best studied by directly observing how diverse zooplankters deal with Phaeocystis colonies.

For an improved assessment of the fate of organic matter derived from Phaeocystis and other algae, it is very important to further elaborate the biomarker approach used by Hamm et al., 2000. For instance, this study showed that Phaeocystis-specific fatty acids and sterols were useful biomarkers to study the fate of rapidly degradable organic matter derived from the colony cells. If specific biomarkers, e.g. sugars (Janse et al., 1996) or amino acids, could be identified for the colony skin, it should be possible to assess how efficient sedimentation of the more refractory colony skin material can be.

\section{Note added in proof}

A recent publication by Di Tullio et al. (2000) demonstrates that cellular material from Phaeocystis antarctica can sink in significant amounts to deeper layers of the Ross Sea during the exponential phase of a phytoplankton bloom. A similar scenario has also been described by Hamm et al. (2000) for Phaeocystis pouchetii in Balsfjorden/Northern Norway. Yet, the vehicles of particle transport seem to differ in these two regions. While the cellular Phaeocystis-derived material in Balsfjorden sank mainly within faecal 
material to deeper layers, Phaeocystis aggregates, which have been shown to sink inefficiently in the North Sea (P. globosa; Riebesell, 1995), seem to dominate export of Phaeocystis-derived cellular organic matter to the Ross Sea sediments. However, while the modes of carbon export out of Phaeocystis blooms may be as multiform as are the manifestations of their colonies or their trophic fates, there is increasing evidence that sedimentation of Phaeocystisderived organic matter must be regarded as a potentially very efficient component of the biological carbon pump.

\section{Acknowledgements}

I thank three anonymous reviewers and Jacqueline Stefels for their helpful comments on the manuscript. This is AWI publication No. 1698.

\section{References}

Admiraal, W., Venekamp, L.A.H., 1986. Significance of tintinnid grazing during blooms of Phaeocystis pouchetii (Haptophyceae) in Dutch coastal waters. Neth. J. Sea Res. 20, 61-66.

Arrigo, K.R., Robinson, D.H., Wothen, D.L., Dunbar, R.D., DiTullio, G.R., Van Woert, M., Lizotte, M.P., 1999. Phytoplankton community structure and the drawdown of nutrients and $\mathrm{CO}_{2}$ in the Southern Ocean. Science 283, 365-367.

Baumann, M.E.M., Lancelot, C., Brandini, F.P., Sakshaug, E., John, D.M., 1994. The taxonomic identity of the cosmopolitan prymnesiophyte Phaeocystis: a morphological and ecophysiological approach. J. Mar. Sys. 5, 5-22.

Bertness, M.D., 1981. Conflicting advantages in resource utilization: the hermit crab housing dilemma. Am. Nat. 118, 432-437.

Bird, D.F., Karl, D.M., 1991. Massive prasinophyte bloom in northern Gerlache Strait. Antarct. J. US 26, 152-154.

Brussaard, C.P.D., Riegman, R., Noordeloos, A.A.M., Cadée, G.C., Witte, H., Kop, A.J., Nieuwland, G., Van Duyl, F.C., Bak, R.P.M., 1995. Effects of grazing, sedimentation and phytoplankton cell lysis on the structure of a coastal pelagic food web. Mar. Ecol. Prog. Ser. 123, 259-271.

Bullen, G.E., 1908. Plankton studies in relation to the western Mackerel fishery. J. Mar. Biol. Ass. UK 8, 269-302.

Cadée, G.C., González, H., Schnack-Schiel, S.B., 1992. Krill diet affects fecal string settling. Polar Biol. 12, 75-80.

Daro, M.H., 1985. Field study of selectivity, efficiency and daily variation in the feeding of the marine copepod Temora longicornis, in the Southern Bight of the North Sea. Int. Symp. Mar. Plankton 37, 764.

Di Tullio, G.R., Grebmeier, J.M., Arrigo, K.R., Lizotte, M.P., Robinson, D.H., Leventer, A., Barry, J.P., Van Woert, M.L., Dunbar, R.B., 2000. Rapid and early export of Phaeocystis antarctica blooms in the Ross Sea, Antarctica. Nature 404, 595-598.

Doers, M.P., Parker, D.L., 1988. Properties of Microcystis aeruginosa and M. flos-aquae (Cyanophyta) in culture: Taxonomic implications. J. Phycol. 24, 502-508.

Eilertsen, H.C., Schei, B., Taasen, J.P., 1981. Investigations on the plankton community of Bals-Fjorden, northern Norway. The phytoplankton 1976-1978. Abundance, species composition, and succession. Sarsia 66, 129-141.

Ertl, H., Hallmann, A., Wenzl, S., Sumper, M., 1992. A novel extensin that may organize extracellular matrix biogenesis in Volvox carteri. EMBO J. 11, 2055-2062.

Estep, K.W., Nejstgaard, J.C., Skjoldal, H.R., Rey, F., 1990. Predation by copepods upon natural populations of Phaeocystis pouchetii as a function of the physiological state of the prey. Mar. Ecol. Prog. Ser. 67, 235-249.

Garrison, D.L., Mathot, S., Gowing, M.M., Kunze, H., Lessard, E.J., 1995. Phytoplankton and microzooplankton community structure in the Ross Sea polynya: November and December 1994. Antarct. J. US 30, 212-214.

Gradinger, R., 1996. Occurrence of an algal bloom under Arctic pack ice. Mar. Ecol. Prog. Ser. 131, 301-305.

Green, J.C., 1976. Corymbellus aureus gen. et sp. nov., a new colonial member of the Haptophyceae. J. Mar. Biol. Ass. UK 56, 31-38.

Grimm, N., Weisse, T., 1985. Die Temperaturabhängigkeit des Wachstums von Phaeocystis pouchetii (Haptophyceae) in Batchkulturen. Helgol. Meeresunters. 39, 201-211.

Guillard, R.R.L., Hellebust, J.H., 1971. Growth and the production of extracellular substances by two strains of Phaeocystis pouchetii. J. Phycol. 7, 330-338.

Hamm, C.E., Simson, D., Merkel, R., Smetacek, V., 1999. Colonies of Phaeocystis globosa are protected by a thin but tough skin. Mar. Ecol. Prog. Ser. 187, 101-111.

Hamm, C.E., Reigstad, M., Riser, C., Wassmann, P., 2000. On the trophic fate of Phaeocystis pouchetii: 7. Sterols and fatty acids reveal sedimentation of Phaeocystis-derived organic matter via krill fecal strings. Mar. Ecol. Prog. Ser. (in press).

Hansen, B., Tande, K.S., Berggreen, U.C., 1990. On the trophic fate of Phaeocystis pouchetii (Hariot). 3. Functional responses in grazing demonstrated on juvenile stages of Calanus finmarchicus (Copepoda) fed diatoms and Phaeocystis. J. Plankton Res. 12, 1173-1187.

Hansen, B., Fotel, F.L., Jensen, N.J., Madsen, S.D., 1996. Bacteria associated with a marine planktonic copepod in culture. 2 . Degradation of fecal pellets produced on a diatom, a nanoflagellate or a dinoflagellate diet. J. Plankton Res. 18, 275-288.

Hansen, F.C., 1992. Zooplankton-grazing an Phaeocystis mit besonderer Berücksichtigung der calanoiden Copepoden. PhD Thesis, University of Kiel, Kiel.

Hansen, F.C., Van Boekel, W.H.M., 1991. Grazing pressure of the calanoid copepod Temora longicornis on a Phaeocystis dominated spring bloom in a Dutch tidal inlet. Mar. Ecol. Prog. Ser. 78, 123-129.

Hansen, F.C., Reckermann, M., Klein-Breteler, W.C.M., Riegman, R., 1993. Phaeocystis blooming enhanced by copepod predation on protozoa: Evidence from incubation experiments. Mar. Biol. 102, 51-57. 
Hansen, P.J., Bjørnsen, P.K., Hansen, B.W., 1997. Zooplankton grazing and growth: scaling within the $2-2000 \mu \mathrm{m}$ body size range. Limnol. Oceanogr. 42, 687-704.

Hanslik, M., Rahmel, J., 1995. Seasonal dynamics of bloom-forming and toxic algae along the coast of Lower Saxony (Niedersachsen, German Bight) since 1982. In: Heise, G., Becker, G.A. (Eds.), Actual problems of the marine environment. Lectures 5th Int. Sci. Symp. Dtsch. Hydrogr. Z., vol. 5, pp. 221-235.

Hollowday, E.D., 1993. Cephalodella edax sp. nov. A rotifer parasitic in the motile colonial alga Uroglena volvox Ehrenberg. In: Gilbert, J.J., Lubzens, E., Miracle, M.R. (Eds.), Sixth Int. Rotifer Symp., Banyoles (Spain), 3-8 Jun. 1991. Hydrobiologia, vol. 255/256, pp. 445-448.

Kühn, S.F., 1997. Rhizamoeba schnepfii sp. nov., a naked amoeba feeding on marine diatoms (North Sea, German Bight). Arch. Protistenkd. 147, 277-282.

Jacobsen, A., Bratbak, G., Heldal, M., 1996. Isolation and characterization of a virus infecting Phaeocystis pouchetii (Prymnesiophyceae). . J. Phycol. 32, 923-927.

Janse, I., Van Rijssel, M., Gottschal, J.C., Lancelot, C., Gieskes, W.W.C., 1996. Carbohydrates in the North Sea during spring blooms of Phaeocystis: a specific fingerprint. Aquat. Microb. Ecol. 10, 97-103.

Janse, I., Van Rijssel, M., Ottema, A., Gottschal, J.C., 1999. Microbial breakdown of Phaeocystis mucopolysaccharides. Limnol. Oceanogr. 44, 1447-1457.

Lancelot, C., Keller, M.D., Rousseau, V., Smith, W.O. Jr., Mathot, S., 1998. Autecology of the marine haptophyte Phaeocystis sp. NATO ASI Series 67, pp. 88-101.

Logan, B.E., Passow, U., Alldredge, A.L., Grossart, H.P., Simon, M., 1995. Rapid formation and sedimentation of large aggregates is predictable from coagulation rates (half-lives) of transparent exopolymer particles (TEP). Deep-Sea Res. II 42, 203-214.

Lürling, M., Van Donk, E., 1997. Morphological changes in Scenedesmus induced by infochemicals released in situ from zooplankton grazers. Limnol. Oceanogr. 42, 783-788.

Marchant, H.J., Nash, G.V., 1986. Electron microscopy of gut contents and faeces of Euphausia superba Dana. In: Hoshiai, T., Nemoto, T., Naito, Y. (Eds.), Proc. Seventh Symp. Polar Biol. National Institute of Polar Research Tokyo (Japan) 40, pp. 167-177.

Parke, M., Green, J.C., Manton, I., 1971. Observations on the fine structure of zoids of the genus Phaeocystis (Haptophyceae). J. Mar. Biol. Ass. UK 51, 927-941.

Passow, U., Alldredge, A.L., 1995. A dye-binding assay for the spectrophotometric measurement of transparent exopolymer particles (TEP). Limnol. Oceanogr. 40, 1326-1335.

Passow, U., Wassmann, P., 1994. On the trophic fate of Phaeocystis pouchetii (Hariot): 4. The formation of marine snow by $P$. pouchetii. Mar. Ecol. Prog. Ser. 104, 153-161.

Raghukumar, C., 1978. Physiology of infection of the marine diatom Licmophora by the fungus Ectrogella perforans. Veröff. Inst. Meeresforsch. Bremerh. 17, 1-14.

Riebesell, U., 1995. Aggregation of Phaeocystis during phytoplankton spring blooms in the southern North Sea. Mar. Ecol. Prog. Ser. 96, 281-289.
Riebesell, U., Reigstad, M., Wassmann, P., Noji, T., Passow, U., 1995. On the trophic fate of Phaeocystis pouchetii (Hariot): 6. Significance of Phaeocystis-derived mucus for vertical flux. Neth. J. Sea. Res. 33, 193-203.

Schnack, S.B., 1983. On the feeding of copepods on Thalassiosira partheneia from the Northwest African upwelling area. Mar. Ecol. Prog. Ser. 11, 49-53.

Schnepf, E., Drebes, G., 1977. Über die Entwicklung des marinen parasitischen Phycomyceten Lagenisma coscinodisci (Lagenidiales). Helgoländer wiss. Meeresunters. 29, 291-301.

Schnepf, E., Drebes, G., 1986. Chemotaxis and appetence of Paulsenella sp. (Dinophyta), an ectoparasite of the marine diatom Streptotheca tamesis Shrubsole. Planta 167, 337-343.

Sieburth, J.McN., 1960. Acrylic acid, an antibiotic principle in Phaeocystis blooms in Antarctic waters. Science 132, 676677.

Small, L.F., Fowler, S.W., Uenlue, M.Y., 1979. Sinking rates of natural copepod fecal pellets. Mar. Biol. 51, 233-241.

Syvertsen, E.E., Hasle, G.R., 1994. Thalassiosira bulbosa Syvertsen, sp. nov., an Arctic marine diatom. Polar. Biol. 3, 167-172.

Tande, K.S., Båmstedt, U., 1987. On the trophic fate of Phaeocystis pouchetii 1 . Copepod feeding rates on solitary cells and colonies of $P$. pouchetii. Sarsia 72, 313-320.

Thingstad, F., Billen, G., 1994. Microbial degradation of Phaeocystis material in the water column. J. Mar. Syst. 5, 55-65.

Tollrian, R., 1995. Predator-induced morphological defenses: costs, life history shifts, and maternal effects in Daphnia pulex. Ecology 76, 1691-1705.

Van Boekel, W.H.M., Hansen, F.C., Riegman, R., Bak, R.P.M., 1992. Lysis-induced decline of a Phaeocystis spring bloom and coupling with the microbial foodweb. Mar. Ecol. Prog. Ser. 81, 269-276.

Van Rijssel, M., Hamm, C.E., Gieskes, W.W.C., 1997. Phaeocystis globosa (Prymnesiophyceae) colonies: hollow structures built with small amounts of polysaccharides. Eur. J. Phycol. 32, 185-192.

Verity, P.G., Smayda, T.J., 1989. Nutritional value of Phaeocystis pouchetii (Prymnesiophyceae) and other phytoplankton for Acartia spp. (Copepoda): Ingestion, egg production, and growth of nauplii. Mar. Biol. 100, 161-171.

Wall, D., Dale, B., 1968. Modern dinoflagellate cysts and evolution of the Peridiniales. Micropaleontology 14, 265-304.

Weisse, T., 1983. Feeding of calanoid copepods in relation to Phaeocystis pouchetii blooms in the German Wadden Sea area off Sylt. Mar. Biol. 74, 87-94.

Weisse, T., Scheffel-Möser, U., 1990. Growth and grazing loss rates in single-celled Phaeocystis sp. (Prymnesiophyceae). Mar. Biol. 106, 153-158.

Weisse, T., Tande, K., Verity, P., Hansen, F., Gieskes, W., 1994. The trophic significance of Phaeocystis blooms. J. Mar. Syst. 5, 67-79.

Zingone, A., Chrétiennot-Dinet, M.J., Lange, M., Medlin, L., 1999. Morphological and genetic characterization of Phaeocystis chordata and P. jahnii (Prymnesiophyceae), two new species from the Mediterranean Sea. J. Phycol. 36, 1322-1337. 